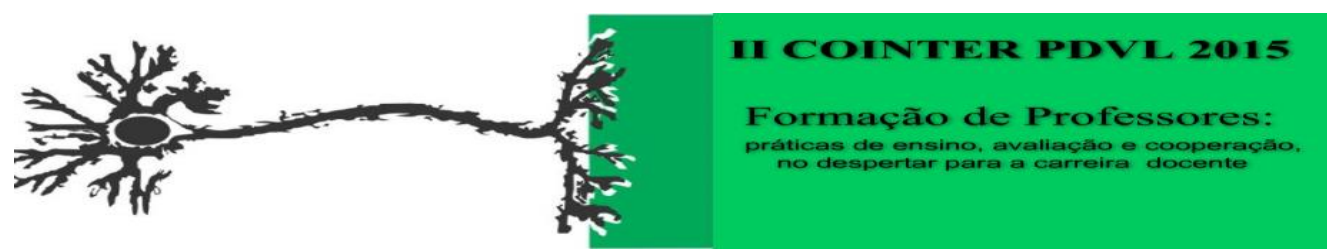

\title{
UMA PROPOSTA DIDÁTICA PARA ABORDAGEM DA HISTÓRIA DA CIÊNCIA NO ENSINO DE FÍSICA UTILIZANDO O TEATRO CIENTÍFICO
}

\author{
Apresentação: Relato de Experiência
}

\author{
Maria Leonete da Silva ${ }^{1}$; Emanoel Silva Carvalho ${ }^{2}$; Simone Ribeiro e Silva ${ }^{3}$; Getúlio \\ Eduardo Rodrigues de Paiva ${ }^{4}$
}

\section{Introdução}

Neste relato, abordam-se a experiência e a possibilidade da utilização do teatro cientifico como uma ferramenta didática através da qual se insere a História da Ciência (HC) no Ensino de Física. A HC nos proporciona um melhor entendimento de como se desenvolve o conhecimento científico, qual a influência o contexto social em que viveram os cientistas teve nas suas pesquisas e teorias científicas, e ajuda a desmistificar a ideia de grandes gênios da ciência, mostrando que o conhecimento não é linear, sendo que a maioria das abordagens feitas pelos livros didáticos dá ênfase aos resultados alcançados destacando nomes e datas como se o conhecimento surgisse de um estalo. Utilizar-se do lúdico para motivar o educando a participar das atividades e proporcionar uma maior aprendizagem dos assuntos abordados é fundamental. Desta forma, procurou-se utilizar o teatro para abordar episódios históricos com o intuito de inserir e promover o contato com a $\mathrm{HC}$ no Ensino de Ciências e Ensino de Física e discutir como se desenvolve o conhecimento científico [1].

\section{Relato de Experiência}

Pensando nas possibilidades e percebendo-se que a maioria dos professores se utiliza de anedotas da História da Física como um fato real, onde ele não demostra a mínima preocupação de saber se realmente aconteceu e ainda na maioria das vezes se utiliza destas apenas como algo introdutório, ou na pior das hipóteses como um passa tempo [2], decidiu-se desenvolver um projeto onde participaram estudantes das turmas do $9^{\circ}$ Ano do Ensino Fundamental ao $3^{\circ}$ ano do Ensino Médio da Escola Estadual Carlos Pena Filho parceira do Programa Institucional de Bolsas de 
Iniciação à Docência (PIBID).

Fez-se um levantamento nas referidas turmas a respeito dos estudantes que gostariam de participar, explicando sobre o objetivo do projeto e como se dariam as atividades. Em seguida, já com os nomes dos participantes, optou-se por realizar a atividades no contra turno das aulas regulares. Iniciou-se o projeto com uma abordagem sobre os aspectos teóricos do teatro, em seguida exercícios práticos de alongamentos e nas demais aulas abordagens a cerca da Física e da História da Ciência, seguidas de discussões de textos científicos e curiosidades dos estudantes. Pouco mais de dois meses trabalhava-se na primeira peça teatral. A qual foi interrompida por uma reforma na escola seguida de uma greve. Então, a partir destes acontecimentos os estudantes começaram a se desmotivar e desistir do projeto. Ainda tentou-se argumentar sobre a importância da atividade articular uma parceria com alguns professores de Artes, mas não se obteve êxito, o que ocasionou o encerramento do projeto.

\section{Considerações}

Este projeto proporcionou discussões interessantíssimas a cerca do desenvolvimento do trabalho científico, bem como de conceitos físicos que eventualmente apareceram como curiosidades dos estudantes. Notou-se através da participação dos alunos que o teatro científico além de desinibir possibilita uma aprendizagem prazerosa e significativa.

Apesar do precoce encerramento do projeto, achou-se por bem relatar a experiência, pois muito o conhecimento gerado nas atividades desenvolvidas foram bastante interessantes.

\section{Referências}

[1] FONSECA, Sarah Suely Nascimento; SANTOS, Elisângela de Andrade; SOUZA, Divanízia do Nascimento. Eixo 6: Educação e Ensino de Ciências Exatas e Biológica. Disponível em: <http://educonse.com.br/2012/eixo_06/PDF/104.pdf〉. Acesso em 08 de fevereiro de 2015.

[2] MARTINS, Roberto. Introdução: A História das Ciências e seus Usos na Educação. Disponível em: <http://www.ghtc.usp.br/server/pdf/RAM-livro-Cibelle-Introd.pdf >. Acesso em: $10 \mathrm{de}$ fevereiro de 2015.

Excluído: ${ }^{1}$ Licenciatura em Física, IF Sertão PE, leonete25@outlook.com.br ${ }^{2}$ Licenciatura em Física, IF Sertão PE, emanoelcarvalho911@hotmail.com q ${ }^{3}$ Licenciatura em Física, Escola Estadual Carlos Pena Filho,

simoneariane08@hotmail.com 9

${ }^{4}$ Mestre em Engenharia Elétrica, IF Sertão

PE, getulio.paiva@ifsertao-pe.edu.brq 